\title{
Uganda hosts banana trial
}

A pioneering breed of genetically modified (GM) banana plant could reach a field site in Uganda as early as next month. The tiny plants, currently awaiting transport at the Catholic University of Leuven, Belgium, are expected to become the first GM bananas to enter field trials in Africa. Although unlikely to replace traditional varieties, they may open the door to other GM crops.

The plants have been genetically modified to resist black sigatoka, a leaf spot disease caused by the fungus Mycosphaerella fijiensis. The disease can reduce banana production by up to $50 \%$, and so is an attractive target for genetic engineering.

Lab tests show that certain genes from rice make bananas less sensitive to the disease, says Rony Swennen of the Laboratory of Tropical Crop Improvement in Leuven, where the work was done. Whether they perform equally well in the field will be tested at the Kawanda Agricultural Research Institute (KARI) of the National Agricultural Research Organisation, based in Kampala. The fruit, like most cultivated bananas, are sterile, which will keep the genes from spreading to other plants.

After India, Uganda is the world's biggest grower of bananas and plantains, producing 10 million tonnes a year for eating or to make beer. Relatively few of these bananas are of the bogoya dessert variety tested in the Belgian lab - but the same genes may protect them, too.

In fact, the genes may reach Uganda before the bananas: Swennen plans to send the relevant DNA constructs to KARI soon, but the bananas must wait for formal approval from the government. The KARI researchers plan to use the genes to modify highland (cooking) bananas, which are a more important food staple. They also want to improve the highland banana's food value. "We are trying to increase the vitamin A and iron content," says Geoffrey Arinaitwe, a Belgium-trained Ugandan researcher working at KARI.

"The main goal of the project with the bogoya dessert banana is capability building in Uganda," adds Swennen, "so that trained local people can do the work themselves."

The Ugandan project is not the only one aimed at black sigatoka. "We are developing bananas with black sigatoka resistance too," says Eli Khayat, vice-president of research at Rahan Meristem, a biotech firm in Western Galilee,

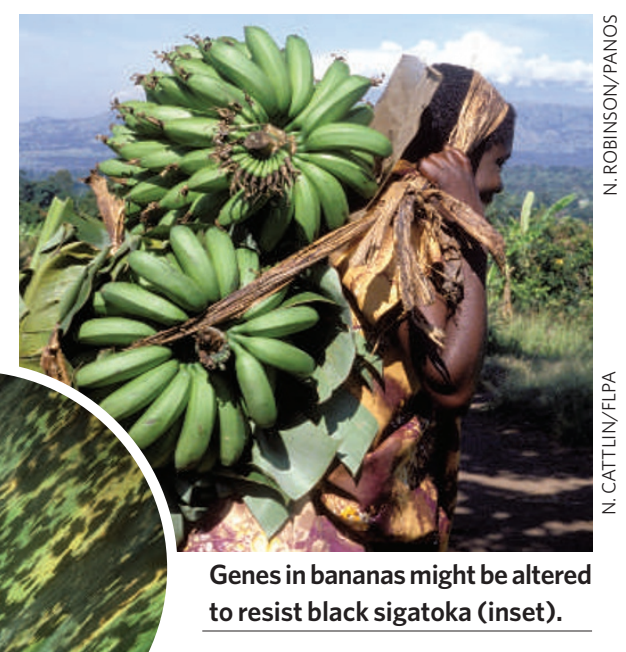

Israel. "But we would probably test them in Central America. Treatments against black sigatoka can cost US $\$ 1,600$ per hectare in Costa Rica."

The Ugandan project receives help and training from the Agricultural Biotechnology Support Project, an international consortium led by Cornell University. The project is funded by the US Agency for International Development - which also finances a programme advising and supporting the Ugandan government in setting up biotech research projects."These two big American projects came in with basically one objective: to get GM bananas in the field as fast as possible," says Richard Markham of Rome-based Bioversity International, a non-governmental organization that oversees several banana projects and helped start the Belgian black sigatoka project.

The trials may not draw the public protest that sometimes accompanies GM trials in Europe and elsewhere. "People have more pressing concerns, like the rebellion in the north, AIDS, droughts and poverty," says Markham.

"Some consumer groups strongly oppose GM organisms," adds Godber Tumushabe of the Advocates Coalition for Development and Environment, a Kampala-based think-tank. "But the debate in Uganda has died down in recent years. When field trials begin, it could start again."

Whatever its reception, the banana project still has a long way to go. But it may have smoothed the path for other GM crops. The Uganda government is currently evaluating an application for Bt cotton, which produces its own insecticidal toxin, and GM cassava is in the pipeline.

Anne Dauwers 